\title{
Study on Function-based Hierarchical Planting Modes of Garden Plant Communities in Residential Area
}

\author{
Ye Zheng ${ }^{\mathrm{a}}$, Shan Lu ${ }^{\mathrm{b}}$, Bo Chen ${ }^{\mathrm{c}}$, Yinan Lai ${ }^{\mathrm{d}}$, Jing Jing ${ }^{\mathrm{e}}$ \\ Zhejiang Sci-Tech University, China \\ a915984256@qq.com, ${ }^{b}$ lushan516@163.com, ${ }^{\text {C4} 490471798 @ q q . c o m, ~}{ }^{d} 827$ \\ 362567@qq.com, ${ }^{e} 276680422 @ q q . c o m$
}

\begin{abstract}
.
A perfect garden plant landscape in residential areas must highly unify both artistry and functionality. Since the liberation, Hangzhou has developed a multiple of unique and successful residential garden landscapes. Taking five typical residential areas in Hangzhou Xiasha New Town as examples, the paper investigates and analyzes the composition, structural hierarchy and functions of plant communities, and finally studies the planting modes of plant communities with both good landscape value and functionality.
\end{abstract}

Keywords: Residential greening; Function; Community hierarchy; Planting mode; Hangzhou Xiasha New Town

\section{Introduction}

Apart from natural aesthetics, plant landscape also provides human beings with many functional benefits ${ }^{[1]}$. In this fast-paced and highly-stressed world, a beautiful residential area may become an ideal space for the fatigued modern people to enjoy spiritual life. Residents not just appreciate the appearance and color of plants, but also highlight the effect of combination between functionality and plant community hierarchy.

Taking the residential areas in Hangzhou Xiasha New Town as examples and considering the regional characteristics of Hangzhou, this paper investigates and studies the plant communities in five typical residential areas in Hangzhou Xiasha New Town, analyzes the functions and hierarchical structures of plant communities in different green spaces, and finally proposes the planting modes of plant communities suitable for residential areas in Hangzhou, thus providing technical and theoretic support for building a beautiful Hangzhou, improving the environmental quality of residential areas and creating a comfortable living environment.

\section{Study content and method}


Overview of investigation areas. Hangzhou is located at the northern part of China' s southeast coast, a central-north subtropical transition zone, with warm and humid climate and distinguishing four seasons and belonging to the central subtropical evergreen broad-leaved woodland vegetation zone $\mathrm{e}^{[2]}$.

Xiasha New Town is located at the east part of Hangzhou downtown and the northern coast of the lower reach of the famous Qiantang River, facing Qiantang River to the east and the south, and adjacent to Jiubao Town to the west and Yuhang District of Hangzhou and Haining City of Jiaxing to the north ${ }^{[3]}$. Xiasha New Town is positioned as the one of the three sub-cities of Hangzhou, a residential area with job-housing balance and the block with most convenient traffic, most developed supporting facilities and modern urban construction among the three sub-cities.

Investigation objects. This paper selects five typical and representative residential areas in Hangzhou Xiasha New Town, i.e., Sharm Garden, East Sea-Unnamed Garden, Shimao Riverside Garden, Poly-East Bay and Wild Wind-Sea-Heaven City. Sharm Garden and East Sea-Unnamed Garden are located in the central area of Xiasha New Town, and the other three located in the eastern part.

Investigation methods. This paper performs, through site investigation, statistics on the composition, structural hierarchy and functions of the plant communities in the residential areas and summarizes the application characteristics and existing problems. Finally, this paper summarizes the hierarchical planting modes of plant communities meeting different green space types and ecological functions within the residential areas by referring to the successful tree type selection and landscaping approaches, thus offering scientific and appropriate reference basis for the planting and landscaping design of residential areas in Hangzhou City.

\section{Analysis of planting hierarchy and functions of plant communities in residential areas of Xiasha New Town}

Due to changes to environment, plants have differences in their life forms, ecological amplitudes and adaptation features, thus occupying certain space and growing to different heights, which results in the hierarchical phenomenon of plant communities. The richer of the environmental conditions, the more hierarchies of plant communities and the more complicated hierarchical structures, such as tropical rainforests which often have five or six complicated hierarchies on which there are a large amount of vines, epiphytes, parasitic plants. On the contrary, the poorer of the environmental conditions, the fewer hierarchies and the less complicated hierarchical structures. In the subtropical region where Hangzhou is located, natural plant communications often have three hierarchies, i.e., arborous layer, bush layer and herbaceous layer. Accordingly, during the planting plan of garden plant communities in residential areas, three planting modes, i.e., three-layer planting mode, two-layer planting mode and one-layer planting mode, could be adopted according to the difference of planting façade forms composed of such three layers ${ }^{[4]}$. The plant 
communities of all such three planting modes have ornamental characteristics. In addition, the different species composition and hierarchical structures determine the functions of plants in different modes such as shading, shadowing and environmental protection in the green space in residential areas (Table 1).

Planting mode of one-layer plant community. One-layer planting mode, which provides a sense of open space, is advantageous for the formation of landscape vision and the utilization of space ${ }^{[5]}$. Generally, this planting mode can be classified into three types, i.e., single-layer arbor, single-layer bush and single-layer herbaceous plant.

Single-layer arbor. Arbors are tall and lush, and may provide shading and shadowing functions in garden landscapes. This planting mode could be composed of one plant or several plants, with the former offering complete and unified landscape effects and the latter providing flexibility and rhythm, which are often seen in residential entrances or central squares. For example, the Ginkgo biloba matrix in the squares of Sharm Garden has equal spacing and is harmonious with the rule-based paving of the square, generating neat and structured activity and rest space under trees.

Single-layer bush. Single-layer bushes are often planted as hedgerows to divide space, form visual barriers and give scoping, preventing and decorating functions. Based on different functions, single-layer bush could be classified as protective fence, boundary fence and ornamental fence ${ }^{[6]}$ (Table 2).

Single-layer herbaceous plant. This planting mode is often combined with pavement in residential areas and in the form of ecological parking space, which may reduce the heat radiation and dusts from ground. Another form is vertical greening, which has the functions of vertical decoration and protection. Based on this investigation, we find that in the residential areas in either central area or the newly-constructed eastern part, the greening landscapes are basically horizontal greening, with few vertical greening. For example, there is no greening facility in the positions such as balcony, bay window and roof, lacking hierarchical aesthetics and the recognition of vertical greening.

Planting mode of two-layer plant community. According to different plant types and planting modes, this planting mode basically includes the arbor-bush (herbaceous plant) and the bush- herbaceous plant modes.

Arbor-bush (herbaceous plant). Arbor-bush (herbaceous plant) combination has a richer spatial plant structure compared with single arbors. According to the canopy density of plants, it could be classified into dense woodland (with a canopy density of 0.7-1.0) and sparse woodland and grassland (with a canopy density of 0.4-0.6).

Table 1 The planting mode and main function 


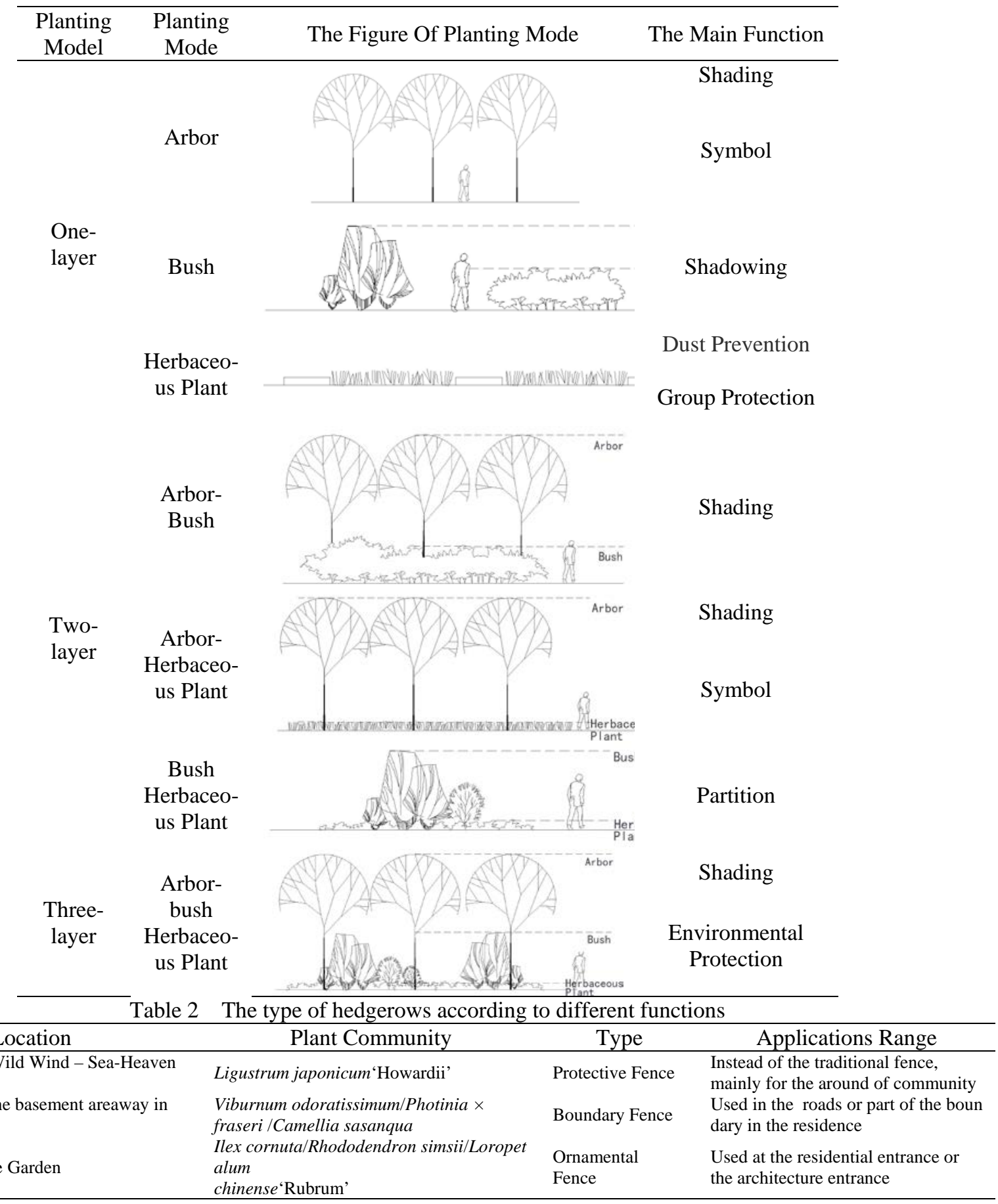

(1)Dense woodland 
Dense woodland refers to the plant configuration with vast arbors and bushes with high density to form woodland and forest landscapes ${ }^{[7]}$. According to the types and quantity, it could be classified as pure woodland and mixed woodland.

Pure woodland is composed of one kind of plant, thus having strong integrity, magnificence and pageantry and being arranged as greening landscape at the residential entrance. For example, the vast Phoenix canariensis woodland at the central square of Shimao Riverside Garden highlights the spatial axis, with the lawn below forming natural separation with the square pavement.

Mixed woodland is a canopy community composed of two or more than two kinds of arbors and bushes, usually serves as the separator of space and background, and is applied in the public greening landscape area in residential areas. For example, the children's play area in Poly - East Bay has the combination of Cinnamomum camphora and Osmanthus fragrans in an enclosed form, generating a space with good shading and excellent sunlight. The middle layer is mainly the bushes such as Ligustrum $\times$ vicaryi, Loropetalum chinense 'Rubrum' and Photinia $\times$ fraseri, with unblocked vision, good ornamental feature and activity space featuring certain isolation and unblocked vision.

(2)Sparse woodland and grassland

Generally, sparse woodland and grassland has sparse top-layer arbors and focuses on low-layer herbaceous plants. Compared with single lawns, it has the function of shading. Arbors are planted in the natural style with small groups and different densities, sizes and heights as well as hierarchical consideration and horizontal coordination ${ }^{[8]}$. Under the arbors are vast perennial root and flowering bulbs, forming dotted lawns and enliven the entirety. In the sparse woodland and grassland of Wild Wind - Sea-Heaven City, the tall Cinnamomum camphoras becomes the focus of the woodland edges, the Magnolia grandiflora and Magnolia denudata enrich the canopy line of the entire plant community, and the Pruns serrulata indicate the changes of seasons, offering the neighboring residents with excellent activity space.

Bush- herbaceous plant. This planting mode adds herbaceous plants based on the single-layer bushes, thus offering a more distinguishing spatial boundary and a softer spatial transition. It is often in the mode of 'flowering bushes flowers' appeared as flower border in residential greening landscapes, that is, it is an application simulating natural woodland edges with multiple wild flowers ${ }^{[9]}$ Flower border may catch the focus of visions of visitors on the bushes and herbaceous plants, and requires bushes and herbaceous plants to have relatively high ornamental value. In residential areas, it often appears in the roads and green space in the form of ribbon or group.

Planting mode of three-layer plant community. The combination of arbors, bushes and herbaceous plants is the simulation of natural plant communities, which is mainly, applied residential greening landscapes. See Fig. 1, the roads in East Sea - Unnamed Garden adopt the combination of arbors and bushes, with highly enclosed plant landscape, good shading effect brought by tall and dense Cinnamomum camphora, and ribbon-shaped Rhododendron simsii and Loropetalum chinense 'Rubrum' stressing road lines and guiding pedestrians. The grasses and flowers may increase the ground artistry and form complete 
plant landscapes. The central greening landscape in residential areas often adopts the enclosed layout, such as for Poly - East Bay as shown in Fig. 2. The grouping with arbors, bushes and herbaceous plants may generate multiple and diversified leisure space, enjoying both ornamental and functional values and meeting the requirements of more residents.
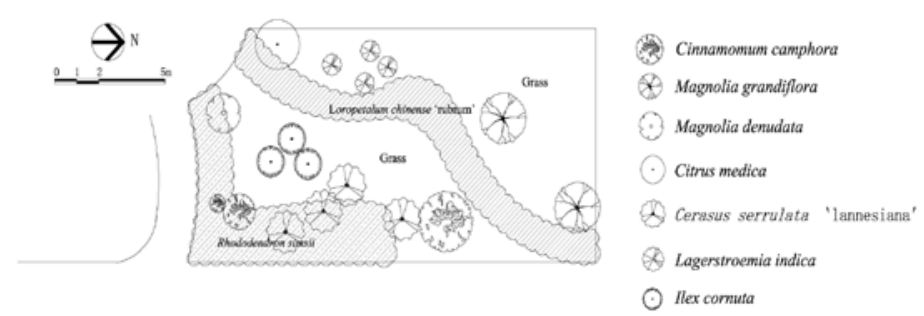

Fig. 1 The sketch map of plant community in the road of East Sea Unnamed Garden

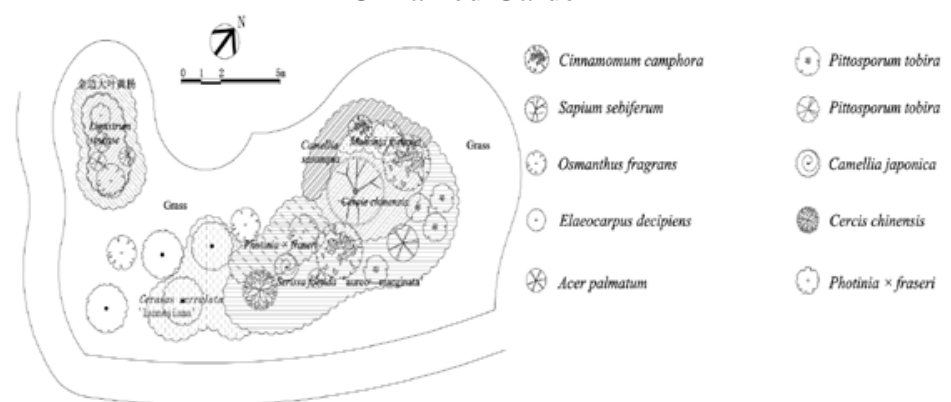

Fig. 2 The sketch map of plant community at the central playing square of East Sea - Unnamed Garden

\section{Discussions and conclusions}

Plants may not only create a beautiful and comfortable environment, but also provide multiple functions and applications such as landmark, shading, shadowing and environmental protection. However, due to different composition and structural hierarchies of plant communities, the functions are completely different. Therefore, in order to give full play to the functions of specific plant communities, we must carry out in-depth consideration for the hierarchies and configurations of plants as the functionality of green space comes first, the functions determine the form of plant community, and the community form serves the green space function. Therefore, during the planting design process of plant communities, we should give priority to the functionality of plant communities and choose different planting and configuration modes accordingly, so as to realize the harmonious unity of plant, landscape and human while meeting all functionality requirements. 
The green space in residential areas can be classified into the following types based on functions: ecological green space, central green space, leisure and recreational green space, landmark green space and protective green space ${ }^{[10]}$.

Planting mode of ecological green space. Ecological green space utilizes the circulation and regeneration functions of ecological systems and maintains the ecological balance within the residential areas. It is often arranged in residential areas or irregular green space, and various hierarchies, types, combinations and changes and high density should be taken into consideration for the structure of plant communities. Therefore, the recommended mode focuses on the 'arbor bush - herbaceous plant' such as Ginkgo biloba / Citrus maxima / Cinnamomum camphora / Liquidambar formosana / Sapindus mukorossi / Osmanthus fragrans / Prunus serrulata / Elaeocarpus decipiens -Loropetalum chinense 'Rubrum' / Ilex cornuta / Euonymus japonicus / Hypericum monogynum / Euonymus japonicus 'Aurea-marginatus' - Ophiopogon japonicus / Cynodon dactylon; Sapium sebiferum / Zelkova serrata / Cinnamomum camphora / Elaeocarpus decipiens / Osmanthus fragrans / Citrus maxima / Magnolia denudata / Lagerstroemia indica / Punica granatum - Photinia X fraseri / Rhododendron simsii / Rosa chinensis / Ligustrum vicaryi / Loropetalum chinense 'Rubrum' - Cynodon dactylon / Zoysia japonica.

Planting mode of central green space. Central green space is a planned concentrated green space benefiting groups, that is, planning one or two concentrated green spaces at the central position of a group, so as to enable the functions such as morning exercise, communication and small parties. It is mainly applied to the greening of public space in residential areas. The recommended modes include arbor - herbaceous plants and arbor - bush (herbaceous plant) (Table 3).

Planting mode of leisure and recreational green space. After leisure time, residents prefer a nearby space for rest and recreation, which are the major mode. So they expect an exclusive small environment to enjoy life. The small parcel of green space around the group may be positioned as leisure and recreational green space, and mainly applied in road greening in residential areas. The recommended modes include: arbor - bush (herbaceous plant), bush - herbaceous plant, and arbor - bush - herbaceous plant (Table 4).

Table 3 Planting mode of central green space

\begin{tabular}{ccl}
\hline $\begin{array}{c}\text { Planting } \\
\text { Mode }\end{array}$ & Type & \multicolumn{1}{c}{ Recommendation Of Planting Mode } \\
\hline & $\begin{array}{c}\text { Sparse } \\
\text { Woodl }\end{array}$ & $\begin{array}{l}\text { Cedrus deodara/Ginkgo biloba/Liquidambar } \\
\text { formosana/Pterocarya stenoptera/Sapindus }\end{array}$ \\
$\begin{array}{c}\text { Arbor-Her } \\
\text { baceous } \\
\text { plant }\end{array}$ & $\begin{array}{c}\text { And } \\
\text { mukorossi-Ophiopogon japonicus/Reineckia } \\
\text { carnea/Poa annua/Festuca elata/Cynodon }\end{array}$ \\
& $\begin{array}{c}\text { nd } \\
\text { dactylon }\end{array}$ \\
Arbor-Bus & Pure & $\begin{array}{l}\text { Metasequoia glyptostroboides/Taxodium distichum/Gink } \\
\text { go biloba/Cinnamomum }\end{array}$ \\
(Herbaceo & Woodl & anphora-Fatsia japonica/Schefflera octophylla \\
us plant) & and & (Ophiopogon japonicus/Reineckia carnea/
\end{tabular}


Oxalis corniculata )

Cinnamomum camphora/Sapium sebiferum/

Osmanthus fragrans/Magnolia denudata-

Camellia japonica/Rhododendron simsii/

Euonymus japonicus 'Rurea-marginatus';

Cinnamomum camphora/Elaeocarpus decipiens/

Prunus serrulata/Osmanthus fragrans/Magnolia denudata-Acer palmatum/Pyracantha fortuneana/Rhodo

Mixed dendron simsii/Hypericum monogynum;

Woodl Trachycarpus fortunei/Phoenix canariensis/Acer

palmatum'Atropurpureum'/Prunus

serrulata-Cycas revoluta/Rhododendron simsii/

Loropetalum chinense 'Rubrum'; Cinnamomum

camphora/Osmanthus fragrans-Pittosporum

tobira/Loropetalum chinense 'Rubrum'/Photinia $\times$

fraseri /Ligustrum $\times$ vicaryi; Cinnamomum

camphora/Trachycarpus fortunei/Phoenix

canariensis/Acer palmatum 'Atropurpureum'/Prunus

serrulata-Cycas revoluta/Rhododendron simsii

Table 4 Planting mode of leisure and recreational green space

\begin{tabular}{|c|c|c|}
\hline Planting Mode & Type & Recommendation Of Planting Mode \\
\hline $\begin{array}{c}\text { Arbor-Bush } \\
\text { (Herbaceous plant) }\end{array}$ & $\begin{array}{c}\text { Mixed } \\
\text { Woodland }\end{array}$ & $\begin{array}{l}\text { Sapium sebiferum/Elaeocarpus decipiens } \\
\text { / } \\
\text { Celtis sinensis/Osmanthus fragrans/Prun } \\
\text { us } \\
\text { serrulata/Punica granatum-Loropetalum }\end{array}$ \\
\hline & & $\begin{array}{l}\text { Chinense } \\
\text { 'Rubrum'/Rhododendron simsii Fig. } 3\end{array}$ \\
\hline $\begin{array}{l}\text { Bush-Herbaceous } \\
\text { plant }\end{array}$ & $\begin{array}{l}\text { Flower } \\
\text { Border }\end{array}$ & $\begin{array}{l}\text { Photinia } \times \text { fraseri/Nandina domestica/ } \\
\text { Mahonia fortunei-Hosta plantaginea/ } \\
\text { Iris tectorum/Hemerocallis fulva }\end{array}$ \\
\hline $\begin{array}{l}\text { Arbor-Bush- } \\
\text { Herbaceous plant }\end{array}$ & $\begin{array}{c}\text { Simulation of } \\
\text { Natural }\end{array}$ & $\begin{array}{l}\text { Cinnamomum } \\
\text { camphora/Elaeocarpus decipiens/ } \\
\text { Citrus maxima-Cycas revoluta/Pittospor } \\
\text { um } \\
\text { tobira/Ilex } \\
\text { crenata'Convexa'/Loropetalum } \\
\text { chinense } \\
\text { 'Rubrum'-Ophiopogon japonicus; } \\
\text { Cinnamomum camphora/Prunus } \\
\text { serrulata-Buxus megistophylla /Hypericu } \\
\text { m } \\
\text { monogvnum-Ophiopogon japonicus:Gink }\end{array}$ \\
\hline
\end{tabular}


go

biloba/Citrus maxima-Photinia $\times$ fraseri/Pittosporum tobira/Loropetalum chinense

'Rubrum'-Cynodon dactylon/Zoysia japonica Fig. 4

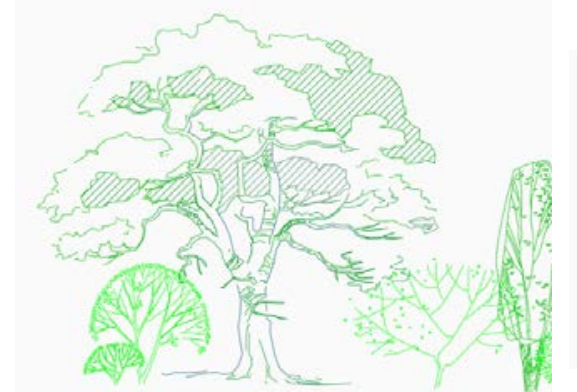

Fig. 3 The sketch map of arbor-bush

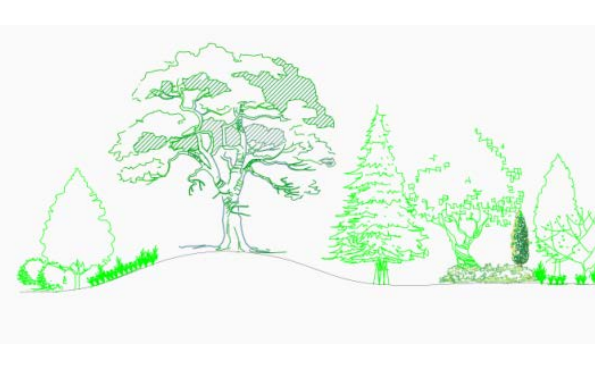

Fig. 4 The sketch map of arbor-bush

Planting mode of landmark green space. Landmark green space is part of the visual environmental design. It aims to attract the attention of people through visual changes of plants. The landmark green space in residential areas are mainly arranged at: vicinity of public organizations, intersections, back lanes, residential areas or building entrances/exits. The recommended planting modes include: arbor, bush and arbor - bush (herbaceous plant) (Table 5).

Table 5 Planting mode of landmark green space

\begin{tabular}{|c|c|c|}
\hline $\begin{array}{l}\text { Planting } \\
\text { Mode }\end{array}$ & Type & Recommendation of Planting Mode \\
\hline Arbor & $\begin{array}{l}\text { Main } \\
\text { Feature } \\
\text { Tree }\end{array}$ & $\begin{array}{l}\text { Ginkgo biloba/Podocarpus macrophyllus/ } \\
\text { Platanus orientalis/Cinnamomum } \\
\text { camphora/Magnolia grandiflora/Phoenix canariensis } \\
\text { Fig. } 5\end{array}$ \\
\hline Bush & $\begin{array}{l}\text { Ornamen } \\
\text { tal Fence }\end{array}$ & $\begin{array}{l}\text { Ilex cornuta/Rhododendron simsii/ } \\
\text { Loropetalum chinense'Rubrum'/Euonymus } \\
\text { japonicus‘Aurea-marginatus';Ilex cornuta/ } \\
\text { Cycas revoluta/Photinia } \times \\
\text { fraseri/Loropetalum chinense 'Rubrum'/ } \\
\text { Euonymus japonicus‘Aurea-marginatus' }\end{array}$ \\
\hline $\begin{array}{l}\text { Arbor-Bush } \\
\text { (Herbaceous } \\
\text { plant) }\end{array}$ & $\begin{array}{l}\text { Main } \\
\text { Feature } \\
\text { Tree }\end{array}$ & $\begin{array}{l}\text { Cinnamomum camphora/Acer } \\
\text { palmatum'Atropurpureum'-Camellia sasanqua-Phoe } \\
\text { nix canariensis-Loropetalum chinense } \\
\text { 'Rubrum'/Euonymus japonicus } \\
\text { 'Aurea-marginatus'/Rhododendron simsi; } \\
\text { Ginkgo biloba-Cycas revoluta Fig. } 6\end{array}$ \\
\hline
\end{tabular}




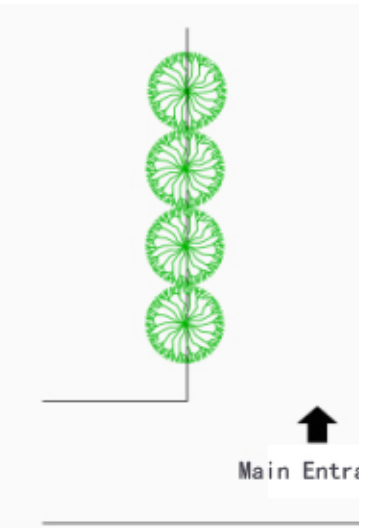

Fig. 5 The sketch map of single-layer arbor at the residential entrance

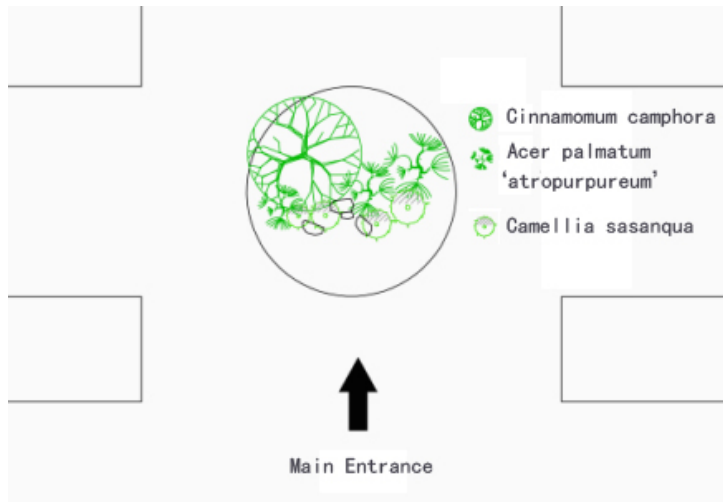

Fig. 6 The sketch map of arbor-bush at the residential entrance

Planting mode of protective green space. Protective green space takes into full consideration the demand that residents enjoy green space, thus choosing the plants with strong capacity of resisting wind, noise and waste and generating useful ions. It is mainly arranged around residential areas or among residential green space. The recommended planting modes include: arbor - bush herbaceous plant (Table 6).

Table 6 Planting Mode Of Protective Green Space

\begin{tabular}{|c|c|c|}
\hline $\begin{array}{l}\text { Planting } \\
\text { Mode }\end{array}$ & Type & Recommendation Of Planting Mode \\
\hline $\begin{array}{l}\text { Arbor-Bu } \\
\text { sh- } \\
\text { Herbaceo } \\
\text { us Plant }\end{array}$ & $\begin{array}{l}\text { Resistin } \\
\text { g Waste }\end{array}$ & $\begin{array}{l}\text { Pinus thunbergii-Forsythia viridissima/Sabina procumbe } \\
\text { ns/Hedera nepalensis;Phoebe chekiangensis/Phoebe she } \\
\text { areri- Fatsia japonica /Aucuba japonica 'Variegata'- } \\
\text { Ophiopogon bodinieri/ Ophiopogon japonicus } \\
\text { Ginkgo biloba/Osmanthus fragrans-Nerium indicum/Pitt } \\
\text { osporum tobira-Ophiopogon bodinieri/Ophiopogon japo } \\
\text { nicus; Cinnamomum } \\
\text { camphora-Punica granatum/Pittosporum tobira-Reineck } \\
\text { ia carnea;Metasequoia glyptostroboides-Viburnum odor } \\
\text { atissimum-Iris tectorum } \\
\text { Platycladus orientalis -Podocarpus macrophyllus/Neriu } \\
\text { m indicum/Ligustrum quihoui-Poa annua;Cinnamomum } \\
\text { camphora/ } \\
\text { Ulmus pumila-Buxus megistophylla/Fatsia japonica-Tric } \\
\text { hoglottis rosea } \\
\text { 'Breviracema';Metasequoia glyptostroboides/ } \\
\text { Ligustrum lucidum-Nerium indicum/Pittosporum tobira; } \\
\text { Ailanthus altissima/Melia azedarach-Alchornea davidii/ } \\
\text { Viburnum odoratissimum }\end{array}$ \\
\hline
\end{tabular}


Sabina chinensis-Podocarpus macrophyllus/Gardenia ja

Protecti sminoides; Cinnamomum

ng camphora/Ginkgo biloba/Osmanthus fragrans/

Health Gardenia jasminoides;Magnolia denudata-Eriobotrya ja ponica/Amygdalus persica-Viburnum macrocephalum

\section{Acknowledgements}

This work was financially supported by the Zhejiang Provincial Natural Science Foundation of China (No. LY12E08023).

\section{References}

[1] Xuehen Su, in: Plant Landscaping (China Forestry Publishing House, 1994) (In Chinese)

[2] Hangzhou Local History Compilation Committee, in: Hangzhou Records, volume I of Progress in Natural and Environment, Zhonghua Book Company (1995) (In Chinese)

[3] Information on http://baike.baidu.com/view/19281.htm

[4] Robinson, Nick, in: The Planting Design Handbook (Ashgate Publishing Company, 2004)

[5] [Japanese] Hiroshi Nakajima, Shuhua Li (Translator), in: Garden Plant Landscaping Manual: From Planning and Design to Construction Management (China Architecture \& Building Press. 2012) (In Chinese)

[6] Dekui Zang, in: Landscape Dendrology (China Architecture \& Building Press, 2009) (In Chinese)

[7] Bo Chen, Jingjing Zhang: Journal of Zhejiang Agricultural Sciences (2011), p.1274-1279 (In Chinese)

[8] Yan Wang,Yi Zhang: China Forestry (2001), p.23 (In Chinese)

[9] Jixiang Zhang, in: Planting Design of Garden Plants. Beijing: China Architecture \& Building Press, 2001(In Chinese)

[10] Wenmin Li,Yuanxiang: Chinese Landscape Architecture (1999) p.06 (In Chinese) 